\title{
The Impact of Perceived Benefits of Corporate Social Responsibility Initiatives on Wetland Farming Communities in Indonesia
}

\author{
LAILA REFIANA SAID ${ }^{1 *}$, HASTIN UMI ANISAH ${ }^{1}$, MUHAMMAD RIZA FIRDAUS ${ }^{1}$, RUSNIATI \\ RUSNIATI $^{1}$, MUHAMMAD KARUNIA RACHMAN ${ }^{1}$ \\ ${ }^{1}$ Faculty of Business and Economics \\ Lambung Mangkurat University \\ Kayutangi, Banjarmasin 70123, South Kalimantan
}

INDONESIA

\begin{abstract}
The Corporate Social Responsibility (CSR) literature has advanced beyond its long-standing emphasis on a firm's financial performance to include its social impact. However, it has fallen short of offering insight into how effective CSR is in the event of a disaster. This study investigated the community's perception of CSR in wetland farmers communities after flood disasters. Data were from 49 farmer groups in South Kalimantan Province, Indonesia. The research hypotheses were drawn: Perceived benefits of CSR initiatives affect farming community resilience, farming community wellbeing, and perceived competence of wetland farmers; Community resilience affects community wellbeing; Community wellbeing and community resilience affect perceived competence of farmers. The structural equation modeling (SEM) analysis showed that CSR initiatives positively affected community resilience and community wellbeing but had no effect on the perceived competence of farmers; Community resilience had a positive effect on community wellbeing. However, both community wellbeing and resilience did not affect perceived competence. This study sheds light on the complex link between the community and the individual. Triple bottom line and community psychology theories were applied, and this study contributes to the social impact of CSR by focusing on both community and individual, especially in the face of natural disasters in wetlands.
\end{abstract}

Key-Words: - community resilience, corporate social responsibility, community wellbeing, Indonesia, perceived competence, wetland

Received: July 15, 2021. Revised: December 18, 2021. Accepted: January 17, 2022. Published: January 18, 2022.

\section{Introduction}

This study investigated the community's perception of Corporate Social Responsibility (CSR) initiatives in Indonesia wetland farming communities. We explore whether communities perceives CSR initiatives to be positive and beneficial; more importantly whether the availability of CSR initiatives influence community resilience, community wellbeing, and the perceived competence of wetland farmers in Indonesia.

There are several reasons why the relationship between variables of this study is important to investigate. First, CSR activities are frequently founded on ideas that conflict with indigenous conceptions of development and community aspirations for connection and interaction [1].
Second, most companies do not design their CSR programs in Indonesia based on community needs assessment or have a clear CSR program direction. They merely wait for the proposal for community assistance [2]. Third, previous research shows that the design of CSR initiatives has not been based on the nature of wetland communities, the programs are spontaneous in response to charity proposals, and companies do not seriously survey areas that need support [3].

Law No. 40. Article 74, 2007 of Indonesia requires industries or companies that use natural resources to implement CSR programs. These industries and companies encourage economic growth by considering social and environmental factors. Implementing CSR programs that are 
perceived to bring benefits to the community is very important because society at large is the company's most important stakeholder.

Some research has explored the perceived benefits of CSR initiatives in Indonesia [4]-[6]. However, very limited research assesses the perceived benefits of CSR initiatives for wetland communities.

The current study also expands the CSR research by looking into the relationship between community and individual. The current study applies the community psychology theory to analyze whether community wellbeing and resilience relate to the farmer's self-competence.

Four main questions were addressed in this study:

- To what extent do CSR initiatives influence community resilience?

- To what extent do CSR initiatives influence community wellbeing?

- To what extent do CSR initiatives influence farmers as individuals?

- To what extent do community wellbeing and community resilience influence farmers as individuals?

\subsection{Environment Management of Wetlands in Indonesia}

The term wetland is used for land affected by water or conditions of standing water, flood tides, floods, and mud. Wetlands have an ecological function and socioeconomic function. The ecological function of wetlands is as a medium of growing plants, absorbents and water storage, carbon storage sites, flood and drought control, and flora and fauna habitats. Wetlands have socioeconomic functions because they benefit from agricultural land, fuel, shelter, recreation areas, forest product providers, fish providers, industrial raw materials, and water sources [7], [8].

In early 2021 one of the provinces with the largest wetland area in Indonesia, South Kalimantan province experienced an unprecedented flash flood natural disaster. Extreme rainfall as an ordinary natural phenomenon turns into a natural disaster because, through large companies, humans massively use the land for business purposes. The company's activities were accused of being a major factor in natural disasters. The impact of business activities of many companies in the wetland area of South Kalimantan related to natural resources within several decades has been realized by the community to be detrimental environmentally and socially.

According to the Agency for the Assessment and Application of Technology of Indonesia, losses from floods in South Kalimantan are approximately IDR 1.349 trillion [9]. In addition to damaged infrastructure losses worth IDR 424.128 billion, losses also include the livestock sector around IDR 8.3 billion, the social protection sector around IDR 27.605 billion, the education sector worth approximately IDR 30.446 billion, the fisheries sector around IDR 46.533 billion, the agricultural sector around IDR 216.266 billion, and in the end the productivity of the people affected by losses of IDR 604.562 billion [9], [10]. Therefore, it is important to examine the impacts of CSR initiatives on the community of wetland farmers.

The wetlands area of Barito Kuala (Batola) Regency, South Kalimantan province in Indonesia, was chosen for the current study because of the following reasons:

1. Batola Regency has a potential agricultural sector on 101,424 hectares of wetlands [11]. The wetland community in Batola Regency generally works as farmers. Wetlands are predominantly used as rice farms, rubber plantations and oil palms. Eighteen thousand twenty-three people are working in the agricultural sector in Batola Regency [12].

2. The need for scientific analysis to improve the competence of wetland farmers. The land ownership area of Batola farmers is grouped into the medium area (0.5-1ha) and large area ( $>1 \mathrm{ha})$, with a lowincome level of less than US\$ 100 per month [12]. Farmers have additional jobs in and out of the agricultural sector to supplement their income. The contribution of income derived from additional work on farmers' overall income ranges from $70 \%$ $91 \%$ [12].

In Indonesia, reclamation of wetlands has been planned massively since the beginning of 1969-1984 era of the first of Five-Year Development Plan through the Tidal Rice Opening Project. The Indonesian Government cleared 5.25 million hectares of land in tidal swamp areas in Sumatra Island (Lampung, South Sumatra, Riau, and Jambi) and Kalimantan/Borneo Island (West Kalimantan, Central Kalimantan, and South Kalimantan, including Barito Kuala regency).

The use of wetlands in Indonesia was initially to increase rice production nationally. In addition, the clearing of wetlands was related to transmigration programs to reduce population density in Java and Bali Islands. Data up to 1995 from the overall location of transmigration, 35\% were placed in 84 wetlands Settlement Units in Kalimantan Island, 201 Settlement Units in Sumatra Island, and 19 Settlement Units in Sulawesi Island [13].

The efforts of transmigrants farmers were directed to agricultural food crops (rice fields) than 
other crops. In terms of wetland clearing policy, the Indonesian Government was stirred by the food crisis in the 1965s. Until 1977, Indonesia had been the largest food importer globally, with $20 \%$ of the share traded globally by importing 2 tons of rice. In 1985 the efforts of the New Order Government since 1969 for Indonesia's rice self-sufficiency were finally achieved [13].

Indonesia's ability to provide food independently has been very volatile. In 1990 Indonesia became an importer of rice, amounting to $10 \%$ of the world market share due to high population growth and rapid land conversion. In 2008, Indonesia achieved self-sufficiency in rice production once again. Nevertheless, a year later, Indonesia has become an importer of rice.

In the National Rice Improvement Program in 2011, the Indonesian Government, through the Directorate General of Food Crops, targeted an additional rice production of 10 million tons for five years to 2015 to meet the national rice reserve goal. The National Rice Improvement Program targeted production optimization in 11 provinces, including large wetland areas in South Kalimantan.

The wetland agriculture sector is considered urgent to be the focus of CSR program initiatives in this study because the impact of floods is felt in 11 districts/cities of South Kalimantan province, which results in crop failure and reduced food supply to the community, as well as impacting the economy [14]. Thus, the current study investigates CSR, which deals with environmental aspects, especially wetlands.

\section{Theoretical Framework, Literature Review and Hypotheses Development}

There were two theoretical frameworks used in this study: the triple bottom line perspective and the community psychology perspective.

\subsection{The Triple Bottom Line Perspective}

CSR emphasizes the importance of three dimensions of responsibility: economic, environmental, and social [15], viewed as dimensions of stakeholder expectations [16]. As a result, specific CSR operating tools, such as the Guidance on Social Responsibility ISO 26000:2010, suggest which actions an operating unit should consider socially responsible concerning stakeholder expectations [17]. There are three parts of CSR responsibility [17]: First, economic responsibility is defined as adopting socially responsible practices in organizational governance (farm management and decision-making) and fair operating procedures by an operating unit. Second, environmental CSR is concerned with the attitudes of socially responsible farmers toward environmental protection, environmental responsibility, agricultural methods, soil deterioration, and conservation. Third, the social part of CSR is fulfilled through socially responsible activities in labor practices, human rights, local community involvement and development, and consumer issues. The current study focuses on the social responsibility part of CSR.

\subsection{Perceived Benefits of CSR Initiatives}

CSR is a mechanism for an organization to voluntarily integrate environmental and social attention in its operations and interactions with stakeholders [18]. CSR is the commitment of business actors to continue to act ethically, operate legally, improve the economy, improve the quality of life of employees and their families, and improve society's quality of life at large. Another definition states that CSR is a business operation that follows or exceeds ethical, legal, trade and public expectations [19]. Many studies infer the influence of CSR perception variables from a company's point of view. Among other things, Shauki [4] found that the perception of CSR performance influences investor decisions to invest in companies.

In the 1950s and 1960s, capitalist business models prioritized profit maximization and free markets. The public realized many companies had committed violations of the rights of their workers and human rights in general [20]. Society demands that companies act more responsibly regarding social aspects, especially when linked to the United Nations declaration of human rights in 1948 [21].

The era of the 1970s was marked by a severe economic crisis around the world. It brings awareness to social movements that champion civil rights, the environment, women and various other issues against corporations [22]. According to Carroll [23], during that time, the purpose of corporate CSR policy was directed to improve the company's image and reputation to achieve social legitimacy.

Since the 1980s, companies that care and intend to carry out CSR activities have increased [24], [25]. The belief of business people that CSR is an economic imperative in national and global markets has increasingly strengthened [26]. The concept of CSR increasingly affects how the business is running. Some companies have re-branding their basic values and incorporated the concept of CSR. 
During the 1980s and 1990s, it began to be manifested in concrete actions against environmental protection, especially in developed countries, and the holding of various world-level meetings to discuss these issues [20].

In the 2000s, market globalization, the company's freedom to run its business, and the complexity of the relationship between the company and various social groups led to a change in its business model [27], [28]. CSR had integrated into the company's business strategy [29]. CSR becomes an important element for companies responding to various social issues [30]. Companies must understand and be assumed to have social responsibility and commitment to stakeholders to operate in various world markets [30]-[32]. In addition, CSR has become a core business part and is the subject of research related to the company's competitive advantage, the efficiency of resource use, and corporate policy with environmental program innovation as the main aspect of CSR [33].

At first, commitment and social responsibility are voluntary received by the company to gain public/market trust. However, over time, many countries require various world companies operating in the country to have a proposal of codes of good practice [20]. Community support or acceptance of industrial activities in a community is important for the company's operations in the region. This acceptance is also referred to as the social license to operate (SLO), where the company meets the community's expectations and the company's activities can be accepted and get approval from residents [34], [35].

Less emphasis has been made on the impact of CSR efforts on communities [36]. The benefits of CSR initiatives need to be well received by the community because companies have set aside funds to carry out various activities as proof of their responsibility. The current study prioritizes community viewpoints by assessing people's perceptions in the wetland community toward the benefits of CSR initiatives. Perceived benefits of CSR initiatives ('Perceived CSR' in short) is defined as an assessment of the perception of wetlands farmers in general about the company's support for disaster-disturbed communities in the form of physical, social, mental, community economic empowerment, and environmental concerns [37]-[40].

\subsection{The Impact of Perceived Benefits of CSR Initiatives on Community Resilience,}

\section{Community Wellbeing, and Perceived Competence}

While the CSR literature has advanced beyond its long-standing emphasis on a firm's financial performance to include its social impact, it has fallen short of offering significant insight into how effective CSR measures are in the event of a disaster. Little research has been conducted in Indonesia on how CSR has enhanced community resilience. Community resilience is the community's ability to respond to significant changes within that community [41]. Resilience is considered a response that produces something different from the original state. Resilience shows that society can adapt and potentially change things better than before. The effect of the CSR program on community resilience in the nickel mining industry in Southeast Sulawesi, Indonesia, showed that CSR positively affects community resilience [5]. Through their CSR initiatives, companies can be responsible and support the community recover from the impact of natural disasters. However, no study conducted specifically assessed the perceived benefits of CSR initiatives on wetland farmers, especially after the flood disaster that destroyed the paddy fields. Thus, the current study's objective was to test the impact of perceived benefits of CSR initiatives on the community resilience of wetland farmers.

Secondary data from the Central Bureau of Statistics shows the absence of facilities, equipment, and community readiness in the face of disasters [42], [43]. Empirical research measuring the benefits of CSR in conjunction with disaster mitigation is still very limited. Therefore, it is important to measure perceived CSR initiatives against the community resilience of farmers, especially in the face of natural disasters in the wetland environment.

Some studies provide preliminary evidence that CSR practices influence community welfare. For example, CSR practices in China and Germany promotes sustainable development and social welfare [44]. Another study shows the benefits of CSR in terms of community wellbeing [45]. Specifically, a study found that local farmers' involvement in CSR activities positively affects community wellbeing [46]. Accordingly, the current study investigates the relationships between the perceived benefits of CSR initiatives and the community wellbeing of wetland farmers.

Community resilience has been considered an important element in achieving community wellbeing [47] by utilizing natural resources and strengthening community capacity, activity, effectiveness, and adaptation [41], [48], [49]. 
Additionally, community resilience disruption (e.g., natural disaster) affects community wellbeing [5]. It is interesting to explore the effect of community resilience on the community wellbeing of wetland farmers.

Most research focuses on CSR's macro-level benefits [50], with less attention paid to the microlevel effects of CSR on individual behaviors and attitudes [51]. For example, CSR is primarily concerned with the external image and reputation of the company [52]. CSR encompasses environmental initiatives as well as the charity and business communities. Perceived benefits of CSR initiatives and perceived competence have been researched in conjunction with customer satisfaction at environmentally concerned hotels [53]. Throughout the authors' knowledge, research on the relationship of perceived benefits of CSR initiatives and the improvement of the competence of wetland farmers, especially after natural disasters, has never been done. So, it is necessary to analyze the relationship between variables, perceived benefits of CSR initiatives and individual competence of farmers in the wetland farming community.

\subsection{The Community Psychology Perspective: Impact of Community Wellbeing and Community Resilience on the Individual Perceived Competence}

Community psychology involves the study of how individuals interact with society. Community is defined as a sense of belonging shared by members; members believe they matter to one another and the group [54]. Its concepts provide valuable frameworks for considering the individual's significance concerning the community. One of the concepts, the sense of community, is intended to describe people's emotions when they view themselves as interconnected with a larger group outside of themselves [55]. More precisely, the sense of community is defined as "the experience of belonging to a wider, dependable, and secure framework" (p. 157). Individuals are influenced by their communities, which means that while analyzing social problems or developing community initiatives (such as facing natural disasters), we must go beyond individual considerations [56]. Personal choices and the dynamic interaction of community elements and individuals determine an individual's wellbeing [57].

In the medical study of Alzheimer's, selfwellbeing and perceived competence are found positively related [58]. Nurses' perceived preparedness is directly related to their prior experience working in a catastrophe or disaster aftermath setting, such as a post-disaster shelter [59]. Those studies are related to empowerment, which has developed into a central concept in community psychology. Psychological empowerment on an individual and community level necessitates heightened awareness and comprehension of the variables that shape our lives. The community's availability of resources may affect an individual's wellbeing or, specifically, selfefficacy [57]. Individual self-efficacy is based on the premise that is simply believing in one's ability (perceived competence) to accomplish a goal is sufficient for self-empowerment. By adapting psychological empowerment in the community psychology theoretical framework, we seek to investigate the impact of community wellbeing and resilience on the individual perceived competence of farmers as they are part of the wetland community.

\subsection{Hypotheses Development}

Considering all preceding concepts and possible impacts of CSR initiatives, the current study seeks to explore the perceived benefits of CSR initiatives concerning community resilience, community wellbeing, and the perceived competence of wetland farmers. This current study proposes the following hypotheses:

H1: Perceived benefits of CSR initiatives positively affect community resilience.

$\mathrm{H} 2$ : Perceived benefits of CSR initiatives positively affect community wellbeing.

H3: Community resilience positively affects community wellbeing.

H4: Community wellbeing positively affects perceived competence.

H5: Community resilience positively affects perceived competence.

H6: Perceived benefits of CSR initiatives positively affect perceived competence.

\section{Data Analysis and Results}

\subsection{Sample Selection, Data Collection, and Instrument Design}

Primary data on respondents' perceptions of CSR, community resilience, community wellbeing, and perceived competence were gathered through 
surveys and interviews. The responses were gathered from all 49 farmer groups from two villages that included heads and some members of the groups. The total data of 100 in the current study was considered sufficient for the structural equation model [60]. All respondents were male. The average age of respondents was 44 years old.

The perceived CSR, community resilience, community wellbeing, and perceived competence aspects were quantified using a five-point Likert scale. The perceived CSR was adapted from previous studies [37]-[40]. The community resilience scale was adapted from Wilson [61], which has three types of capital: social, environmental, and economic. The wellbeing scales were adapted from Devine-Wright [62], McCrea, Walton and Leonard [48] [49], and Walton, Mccrea and Leonard [41]. The dimensions of community wellbeing were classified into seven broad domains (social, economic, environmental, physical, political, health, and place attachment), each of which was assumed to contribute to a more comprehensive measure of community wellbeing. Last but not least, the perceived competence was developed that include knowledge, skill, and expertise dimensions for this study.

\subsection{Measurement Model}

Convergent and discriminant validity were investigated using a series of confirmatory factor analyses (CFAs). SPSS AMOS 24 was used to calculate the goodness of fit for all variables. Figure 1 shows the final measurement models with factor loadings determined to be significant at the 0.05 level, indicating convergent validity [63].

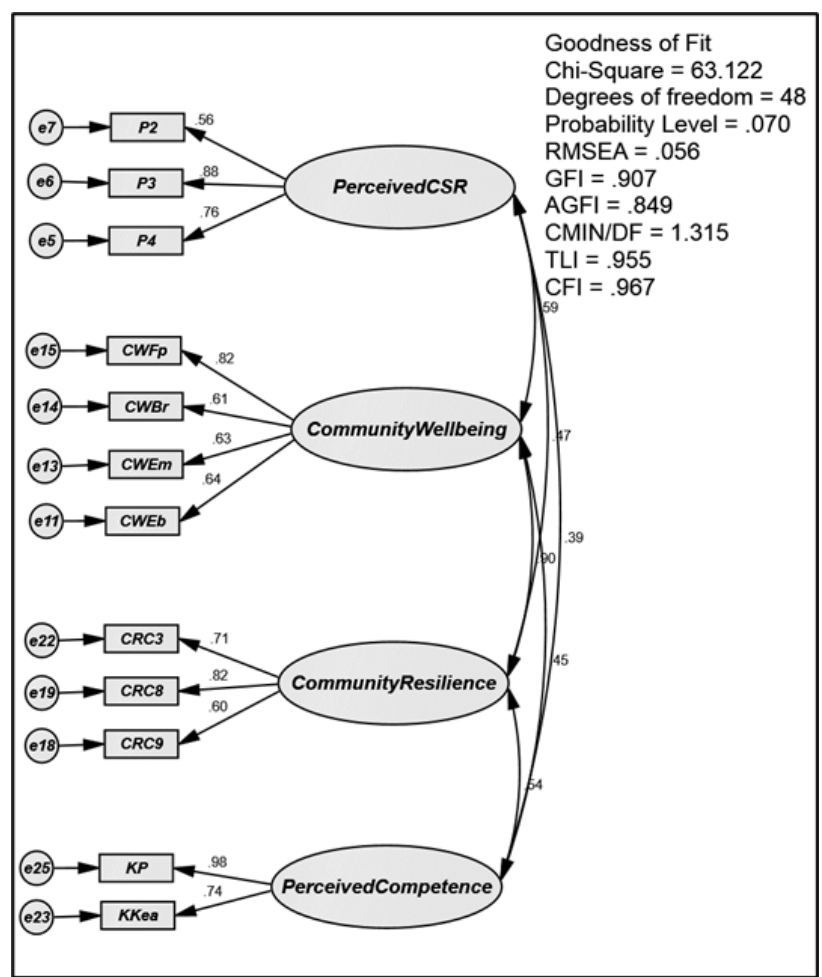

Fig 1. The final measurement model

Furthermore, the average variance extracted (AVE) values were tested to strengthen the convergent validity results with the criteria if the AVE value $>0.5$. All current study constructs had an AVE value of more than 0.5. These scores showed that the indicators of the latent constructs had good convergent validity (Table1).

Table 1. Construct validity and reliability

\begin{tabular}{|c|c|c|c|c|}
\hline Construct & Item & $\begin{array}{l}\text { Factor } \\
\text { loading }\end{array}$ & AVE & CR \\
\hline \multirow{3}{*}{$\begin{array}{l}\text { Perceived } \\
\text { CSR }\end{array}$} & $\begin{array}{l}\text { The companies } \\
\text { cooperate with local } \\
\text { businesses (e.g., } \\
\text { buying relief items in } \\
\text { community-owned } \\
\text { stores) to help the } \\
\text { surrounding } \\
\text { communities affected } \\
\text { by the disaster }\end{array}$ & 0.557 & \multirow[t]{3}{*}{0.623} & \multirow[t]{3}{*}{0.858} \\
\hline & $\begin{array}{l}\text { The companies help } \\
\text { social problems in } \\
\text { communities affected } \\
\text { by the disaster }\end{array}$ & 0.882 & & \\
\hline & $\begin{array}{l}\text { The companies } \\
\text { organize social } \\
\text { projects for vulnerable } \\
\text { groups affected by } \\
\text { disasters }\end{array}$ & 0.762 & & \\
\hline \multirow[b]{3}{*}{$\begin{array}{l}\text { Community } \\
\text { wellbeing }\end{array}$} & $\begin{array}{l}\text { Satisfaction with the } \\
\text { facilities and services } \\
\text { in the community }\end{array}$ & 0.824 & \multirow[b]{3}{*}{0.557} & \multirow[b]{3}{*}{0.849} \\
\hline & $\begin{array}{l}\text { Satisfaction with built } \\
\text { environment and road } \\
\text { in the community }\end{array}$ & 0.607 & & \\
\hline & $\begin{array}{l}\text { Satisfaction with } \\
\text { environmental } \\
\text { management in the } \\
\text { community }\end{array}$ & 0.628 & & \\
\hline
\end{tabular}




\begin{tabular}{|l|l|l|l|l|}
\hline & $\begin{array}{l}\text { Satisfaction with } \\
\text { employment and } \\
\text { business opportunities } \\
\text { in the community }\end{array}$ & 0.641 & & \\
\hline $\begin{array}{l}\text { Community } \\
\text { resilience }\end{array}$ & $\begin{array}{l}\text { Villagers can } \\
\text { effectively access } \\
\text { relevant information to } \\
\text { be able to deal with } \\
\text { changes due to } \\
\text { disasters }\end{array}$ & 0.714 & 0.595 & 0.841 \\
\cline { 2 - 3 } & $\begin{array}{l}\text { Overall, I am satisfied } \\
\text { with the way the } \\
\text { community responded } \\
\text { to the changes in the } \\
\text { village }\end{array}$ & 0.818 & & \\
\cline { 2 - 3 } & $\begin{array}{l}\text { In general, the people } \\
\text { in my village can } \\
\text { adapt to changes due } \\
\text { to disasters }\end{array}$ & 0.604 & & \\
\hline Perceived & Farming skill & 0.744 & 0.783 & 0.917 \\
\cline { 2 - 3 } competence & Farming knowledge & 0.984 & & \\
\hline
\end{tabular}

Construct reliability test was calculated to establish the internal consistency of the relationships between individual items on the measurement scales and confirm the relationships in each factor. As shown in Table 1, the constructs were adequate in terms of composite reliability (CR), with values of $>0.70$ [60], [64], [65].

\subsection{Structural Model}

The structural model (Figure 2) was subjected to multiple satisfactory goodness of fit indices (ChiSquare $=63.122, \mathrm{Df}=48, \mathrm{Chi}$-square $/ \mathrm{DF}=1.315$, Root Mean Square Error of Approximation $[$ RMSEA $]=0.056$, Goodness of Fit Index $[\mathrm{GFI}]=$ 0.907, Adjusted Goodness of Fit Indices [AGFI] = 0.849, Tucker-Lewis Index [TLI] $=0.955$, Comparative Fit Index $[\mathrm{CFI}]=0.967$ ).

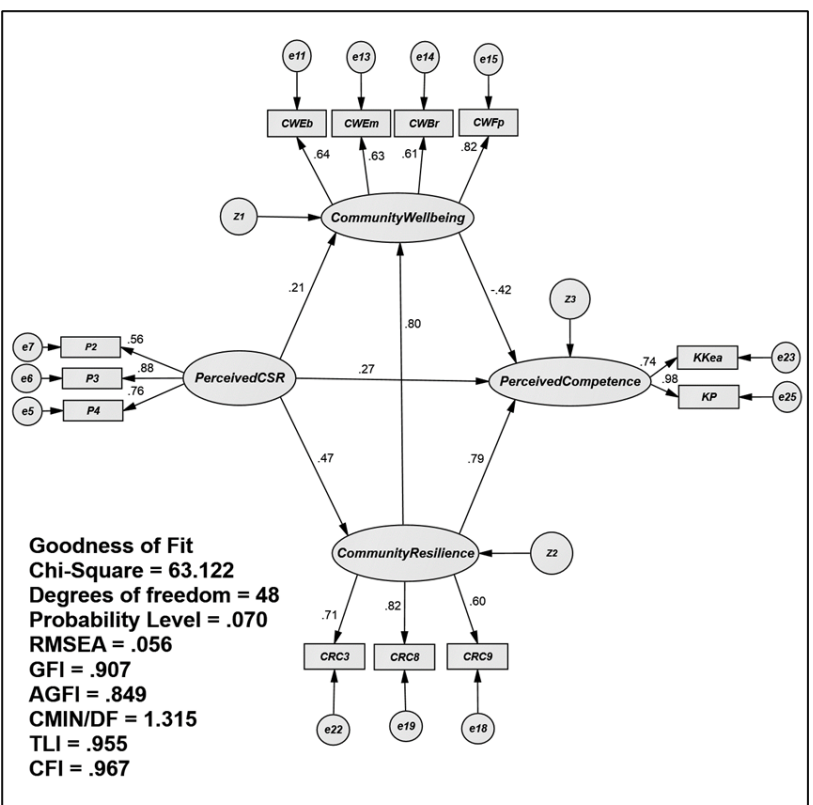

Fig 2. The structural model
Table 2 summarizes the standardized estimates and associated $95 \%$ and $90 \%$ confidence intervals. As shown in Table 2, perceived CSR has a statistically significant effect on community resilience and wellbeing, supporting $\mathrm{H} 1$ and $\mathrm{H} 2$. Community resilience positively affects community wellbeing, which supported $\mathrm{H} 3$.

Additionally, this study hypothesized that perceived competence was influenced by community wellbeing, community resilience, and perceived CSR (H4, H5, and H6). However, community wellbeing, resilience, and perceived CSR did not affect perceived competence, thus rejecting $\mathrm{H} 4, \mathrm{H} 5$, and $\mathrm{H} 6$ (Table 2).

Table 2. The structural model's regression and the test results for hypotheses

\begin{tabular}{|l|l|l|l|l|l|}
\hline Hypothesis & Estimate & S.E. & C.R. & $\begin{array}{l}\boldsymbol{P} \text { - } \\
\text { value }\end{array}$ & Decision \\
\hline $\begin{array}{l}\text { H1: } \\
\text { PerceivedCSR } \rightarrow \\
\text { CommunityResilience }\end{array}$ & 0.295 & 0.086 & 3.434 & $* * *$ & Supported \\
\hline \begin{tabular}{l} 
H2: $\begin{array}{l}\text { PerceivedCSR } \rightarrow \\
\text { CommunityWellbeing }\end{array}$ \\
\hline $\begin{array}{l}\text { H3: } \\
\text { CommunityResilience } \rightarrow \\
\text { CommunityWellbeing }\end{array}$
\end{tabular} & 0.216 & 0.112 & 1.920 & $0.055^{*}$ & Supported \\
\hline $\begin{array}{l}\text { H4: } \\
\text { CommunityWellbeing } \rightarrow \\
\text { PerceivedCompetence }\end{array}$ & -.356 & .460 & -.775 & .438 & Rejected \\
\hline $\begin{array}{l}\text { H5: } \\
\text { CommunityResilience } \rightarrow \\
\text { PerceivedCompetence }\end{array}$ & 1.126 & 0.743 & 1.515 & 0.130 & Rejected \\
\hline $\begin{array}{l}\text { H6: } \\
\text { PerceivedCSR } \rightarrow \\
\text { PerceivedCompetence }\end{array}$ & 0.238 & 0.147 & 1.616 & 0.106 & Rejected \\
\hline
\end{tabular}

\section{Discussion}

Compared to research that explores CSR's relationship to corporate profitability, research on the social impact of CSR is less frequent [66]. In a study of CSR implementation approach in Indonesia, Indarti and Efni [67] categorize three typical implementation models: First, companies run their CSR initiatives by providing direct assistance to the public; Second, they contribute financial support to their foundation or social group; Third, develop collaborative relationships with nongovernmental groups, government agencies, and educational institutions; and Fourth, businesses become a social institution [67]. CSR initiatives in this study fall into the first category, companies directly contribute to the community. In the aftermath of the flood disaster, the assistance provided was donating food and medicine to the communities affected by the disaster.

This study examined the effect of perceived benefits of CSR initiatives on community resilience, community wellbeing, and the perceived competence of wetland farmers. The findings reveal perceived benefits of CSR initiatives positively 
affect community resilience. Although the result shows a significant influence of perceived benefits of CSR initiatives on community wellbeing, the effect was small $(p<0.10)$. It is likely due to this study's wellbeing measurement indicators such as: 'Built environment and road', 'Facilities and services, 'Employment and business opportunities, and 'Environmental management' while the respondents views CSR initiatives not as community development in terms of infrastructure development as confined in the measurement. Although most respondents responded that assistance from companies after the flood disaster had been well received, the assistance was viewed as sporadic.

The infrastructure development support from the company is needed in both regions, and the company is perceived responsible for environmental management. Based on interviews, the farming community needs assistance in disaster anticipation and preparedness, such as safe crop storage containers to avoid being carried away by floods. In addition, agricultural infrastructure such as rice field irrigation channels is highly in demand. So that when flooding happens, the water can immediately recede, and the land can be immediately replanted.

CSR is largely concerned with the organization's external image [52]. It encompasses environmental initiatives as well as the charity and business communities. Most research focuses on CSR's macro-level effects [50], with the micro-level effects of CSR on individuals' behaviors and attitudes receiving less attention [51]. The majority of prior research has examined the effect of perceived benefits of CSR initiatives on the community as a whole effect [4]-[6], [41], but few have examined the individual.

In the current study, the perceived benefit of CSR initiatives did not influence perceived competence. This finding contradicts previous research in environmentally concerned hotels, indicating a correlation between two variables [53]. The different finding is likely due to the CSR initiatives in the current study being intended specifically for after flood disasters support instead of wetland agriculture sustainability in general. Wetlands farmers perceive CSR initiatives were not directly related to agricultural benefit targets. Initiatives after flood disasters were mere as emergency aids, such as food and medicines.

Based on interviews, farmers need seeds for farming and plantations that match the characteristics of wetlands. CSR initiatives are needed in seedlings and training for agricultural development and alternative business creativity as part of sustainable development programs. Training is needed to improve the competence of farmers to support income when floods occur and when rice farming activities are completely paralyzed.

Corroborate prior research indicates that community resilience influenced community wellbeing [5], [6], [41], [47], [48]. By investigating the relation of those variables in the wetland farming communities, this current study extends the validation of the nature of the related effect of community resilience on community wellbeing of wetland farming.

Last but not least, this study proposed a community effect on the individual wetland farmers. We hypothesized that community wellbeing and community resilience could influence the perceived competence of wetland farmers. However, the study findings indicate that community wellbeing and resilience did not affect perceived competence. The outcomes of this study show that community does not necessarily empower individuals. Thus, this study sheds light on the complex link between community and individual from the perspective of community psychology [56], [57].

Our research contributes to the current knowledge on the social impact of CSR by focusing on both community and individual. The study applied the triple bottom line theory [15], [68] and community psychology theory [68]. The research's theoretical implication is in completing the analysis of variables related to the perceived benefit of CSR. The impact of CSR is also analyzed on individual variables as part of the community.

This research's practical/managerial implication is the need to design CSR initiatives according to the needs of farming communities and wetland characteristics. In addition to emergency assistance, CSR initiatives need to focus on the sustainable development of wetland farming. CSR initiatives should be structured and planned towards developing modern wetland farming communities. It includes modern marketing of agricultural products that directly benefit farmers and not just intermediaries.

CSR initiatives would effectively contribute to community development when stakeholder collaborative techniques are used [69]. Communication and coordination among stakeholders, such as the company, farming community, and Government, are needed to improve the competence of farmers and environmental management following the characteristics of wetlands. Practical training in planting or gardening plants other than paddy fields is considered necessary by farmers. 


\section{Conclusion, Limitations and Future Research}

Research findings indicate:

1. The perceived benefit of CSR initiatives has a positive and significant effect on community resilience.

2. The perceived benefit of CSR initiatives has a positive and significant effect on community wellbeing.

3. Community resilience has a positive and significant effect on community wellbeing.

4. Community wellbeing has no significant effect on perceived competence.

5. Community resilience has no significant effect on perceived competence.

6. The perceived benefit of CSR initiatives has no significant effect on perceived competence.

Some limitations should be addressed in the current research. First, it is related to the sample that only gathered the chairman of the farmer group and some of its members in two sub-districts. The upcoming research should utilize a larger sample so that the characteristics of wetland farmers are better represented. Data from other wetlands in other countries should be obtained. Second, this study was cross-sectional. Future research should employ a longitudinal approach to investigate a similar framework. Another limitation is retrieving attitude and behavioral data, a perception variable did on one side only, i.e. from the farmers' perspective. Future research should incorporate data from other sources, such as interviews with companies and other stakeholders, to cross-check statements more objectively. In doing so, the more complex model that investigates the intervening effects could be investigated.

\section{References:}

[1] E. Gilberthorpe and G. Banks, Development on whose terms?: CSR discourse and social realities in Papua New Guinea's extractive industries sector, Resour. Policy, vol. 37, no. 2, pp. 185-193, Jun. 2012, doi: 10.1016/j.resourpol.2011.09.005.

[2] H. Asmu'i and V. P. Damayanti, Kemiskinan Masyarakat Petani di Kecamatan Gambut dan Corporate Social Responsibility dalam Implementasinya, 2015.

[3] L. R. Said, F. Swandari, and M. Said, CSR programs of municipal water utility companies for wetland communities of South Kalimantan, Estud. Econ. Apl., vol. 39, no. 4, 2021, doi: 10.25115/eea.v39i4.4480.
[4] E. Shauki, Perceptions on corporate social responsibility: A study in capturing public confidence, Corp. Soc. Responsib. Environ. Manag., vol. 18, no. 3, pp. 200-208, May 2011, doi: 10.1002/csr.267.

[5] I. Zainuddin Rela, A. H. Awang, Z. Ramli, Y. Taufik, S. Md Sum, and M. Muhammad, Effect of corporate social responsibility on community resilience: Empirical evidence in the nickel mining industry in Southeast Sulawesi, Indonesia, Sustainability, vol. 12, no. 4, p. 1395, Feb. 2020, doi: 10.3390/su12041395.

[6] I. Z. Rela, A. H. Awang, Z. Ramli, S. Md Sum, and M. Meisanti, Effects of environmental corporate social responsibility on environmental well-being perception and the mediation role of community resilience, Corp. Soc. Responsib. Environ. Manag., vol. 27, no. 5, pp. 2176-2187, Sep. 2020, doi: 10.1002/csr.1956.

[7] V. D. Phillips, Peatswamp ecology and sustainable development in Borneo, Biodivers. Conserv., vol. 7, no. 5, pp. 651671, 1998.

[8] A. Wibowo, Peran lahan gambut dalam perubahan iklim global, Tekno Hutan Tanam., vol. 2, no. 1, pp. 19-28, 2009.

[9] M. Herlinawati, Kerugian akibat banjir Kalimantan Selatan diperkirakan Rp1,349 triliun, Antaranews.com, 2021. https://www.antaranews.com/berita/1966136 /kerugian-akibat-banjir-kalimantan-selatandiperkirakan-rp1349-triliun (accessed Jan. $25,2021)$.

[10] U. Maskuriah and L. Thohir, Kerugian akibat banjir di sektor peternakan Kalsel Rp8,3 miliar, Antaranews.com, 2021. https://www.antaranews.com/berita/1982499 /kerugian-akibat-banjir-di-sektor-peternakankalsel-rp83-

miliar?utm_source $=$ antaranews\&utm_mediu $\mathrm{m}=$ related\&utm_campaign $=$ related_news (accessed Feb. 04, 2021).

[11] Syarifuddin, D. Arisanty, and S. Adyatma, Evaluasi kesesuaian lahan padi sawah di Kecamatan Marabahan Kabupaten Barito Kuala Provinsi Kalimantan Selatan, in Seminar Nasional Pendidikan IPS, 2018, pp. 447-458.

[12] N. H. Khairisa, J. Sartohadi, and M. A. Setiawan, Analisis karakteristik sosial ekonomi petani lahan gambut di Kabupaten Barito Kuala, J. Geogr. Apl. dan Teknol., vol. 5, no. 1, pp. 87-94, 2021. 
[13] D. Nursyamsi and M. Noor, Lahan Rawa sebagai Lumbung Pangan Masa Depan, 2019.

[14] M. Zulfikar, 11 kabupaten dan kota terancam gagal panen akibat banjir Kalsel, Antaranews.com, 2021. https://www.antaranews.com/berita/1958496 /11-kabupaten-dan-kota-terancam-gagalpanen-akibat-banjir-kalsel (accessed Jan. 20, 2021).

[15] J. Elkington, Cannibals with forks - Triple bottom line of 21st century business. Stoney Creek, CT: New Society Publishers, 1997.

[16] M. Friedman, The social responsibility of business is to increase its profits, in Corporate Ethics and Corporate Governance, Springer, 2007, pp. 173-178.

[17] R. Vilkè, Ž. Gedminaitè-Raudonè, T. Baležentis, and D. Štreimikienè, Farmers' awareness of eco-efficiency and cleaner production as environmental responsibility: Lithuanian case, Corp. Soc. Responsib. Environ. Manag., vol. 28, no. 1, pp. 288298, 2021, doi: 10.1002/csr.2049.

[18] R. Kusumadilaga, Pengaruh Corporate Social Responsibility Terhadap Nilai Perusahaan Dengan Profitabilitas Sebagai Variabel Moderating (Studi Empiris pada Perusahaan Manufaktur yang terdaftar di Bursa Efek Indonesia), Universitas Diponegoro, 2010. [Online]. Available: http://eprints.undip.ac.id/22572/

[19] Business for Social Responsibility, Issue Brief: Overview of Corporate Social Responsibility, 2003. [Online]. Available: http://www.bsr.org/CSRResources/IssueBrie fDetail.cfm?DocumentID=48809

[20] S. Rodriguez-Gomez, M. L. Arco-Castro, M. V. Lopez-Perez, and L. Rodríguez-Ariza, Where does CSR come from and where does it go? A review of the state of the art, Adm. Sci., vol. 10, no. 3, p. 60, Aug. 2020, doi: 10.3390/admsci10030060.

[21] P. Gomez-Carrasco, E. Guillamon-Saorin, and B. Garcia Osma, The illusion of CSR: drawing the line between core and supplementary CSR, Sustain. Accounting, Manag. Policy J., vol. 7, no. 1, pp. 125-151, Mar. 2016, doi: 10.1108/SAMPJ-12-20140083.

[22] A. B. Carroll and K. M. Shabana, The business case for corporate social responsibility: A review of concepts, research and practice, Int. J. Manag. Rev., vol. 12, no. 1, pp. 85-105, 2010.
[23] A. B. Carroll, A history of corporate social responsibility: Concepts and practices, in The Oxford Handbook of Corporate Social Responsibility, vol. 1, 2008.

[24] M. E. Drumwright, Socially responsible organizational buying: Environmental concern as a noneconomic buying criterion, J. Mark., vol. 58, no. 3, pp. 1-19, 1994, doi: $10.2307 / 1252307$.

[25] P. R. Varadarajan and A. Menon, Causerelated marketing: A coalignment of marketing strategy and corporate philanthropy, J. Mark., vol. 52, no. 3, pp. 58-74, 1988, doi: 10.2307/1251450.

[26] S. Sen and C. B. Bhattacharya, Does doing good always lead to doing better? Consumer reactions to corporate social responsibility, $J$. Mark. Res., vol. 38, no. 2, pp. 225-243, 2001, [Online]. Available: http://www.jstor.org/stable/1558626

[27] N. Cornelius, J. Wallace, and R. Tassabehji, An analysis of corporate social responsibility, corporate identity and ethics teaching in business schools, J. Bus. Ethics, vol. 76 , no. 1 , pp. 117-135, Oct. 2007, doi: 10.1007/s10551-006-9271-6.

[28] L. Shnayder, F. J. van Rijnsoever, and M. P. Hekkert, Motivations for Corporate Social Responsibility in the packaged food industry: An institutional and stakeholder management perspective, J. Clean. Prod., vol. 122, pp. 212-227,__2016,__doi: https://doi.org/10.1016/j.jclepro.2016.02.030

[29] L. Arco- Castro, M. V. López- Pérez, M. C. Pérez- López, and L. Rodríguez- Ariza, How market value relates to corporate philanthropy and its assurance. The moderating effect of the business sector, Bus. Ethics A Eur. Rev., vol. 29, no. 2, pp. 266281, Apr. 2020, doi: 10.1111/beer.12264.

[30] D. Jamali, A Stakeholder Approach to Corporate Social Responsibility: A Fresh Perspective into Theory and Practice, J. Bus. Ethics, vol. 82, no. 1, pp. 213-231, 2008, doi: 10.1007/s10551-007-9572-4.

[31] M. Panait, M. C. Voica, and I. Radulescu, The activity of capital market' actors: Under the sign of social responsibility, Procedia Econ. Financ., vol. 8, pp. 522-528, 2014, doi: $\quad$ https://doi.org/10.1016/S22125671(14)00123-3.

[32] C. Tello Castrillón and M. del P. Rodríguez Córdoba, Conceptual categories of the study organizational social responsibility, 
Hallazgos, vol. 11, no. 22, pp. 119-135, 2014.

[33] I. García- Sánchez and C. Araújo- Bernardo, What colour is the corporate social responsibility report? Structural visual rhetoric, impression management strategies, and stakeholder engagement, Corp. Soc. Responsib. Environ. Manag., vol. 27, no. 2, pp. 1117-1142, Mar. 2020, doi: 10.1002/csr.1869.

[34] N. Gunningham, R. A. Kagan, and D. Thornton, Social license and environmental protection: Why businesses go beyond compliance, Law Soc. Inq., vol. 29, no. 2, pp. 307-341, 2004.

[35] K. Moffat and A. Zhang, The paths to social licence to operate: An integrative model explaining community acceptance of mining, Resour. Policy, vol. 39, pp. 61-70, Mar. 2014, doi: 10.1016/j.resourpol.2013.11.003.

[36] S. McLennan and G. Banks, Reversing the lens: Why corporate social responsibility is not community development, Corp. Soc. Responsib. Environ. Manag., vol. 26, no. 1, pp. 117-126, 2019, doi: 10.1002/csr.1664.

[37] I. Maignan and O. C. Ferrell, Measuring corporate citizenship in two countries: The case of the United States and France, J. Bus. Ethics, vol. 23, no. 3, pp. 283-297, 2000, doi: 10.1023/A:1006262325211.

[38] I. Maignan and O. . Ferrell, Antecedents and benefits of corporate citizenship: An investigation of French businesses, J. Bus. Res., vol. 51, no. 1, pp. 37-51, Jan. 2001, doi: 10.1016/S0148-2963(99)00042-9.

[39] A. H. Crespo and I. R. del Bosque, Influence of corporate social responsibility on loyalty and valuation of services, J. Bus. Ethics, vol. 61, no. 4, pp. 369-385, 2005.

[40] A. Pérez and I. Rodríguez del Bosque, Measuring CSR image: Three studies to develop and to validate a reliable measurement tool, J. Bus. Ethics, vol. 118, no. 2, pp. 265-286, Dec. 2013, doi: 10.1007/s10551-012-1588-8.

[41] A. Walton, R. McCrea, and R. Leonard, CSIRO survey of Community Wellbeing and responding to change: Western Downs region in Queensland, no. September. Queensland, Australia, 2014.

[42] BPS-Statistics of Barito Kuala Regency, Kecamatan Jejangkit dalam Angka 2021, 2021.

[43] BPS-Statistics of Barito Kuala Regency, Kecamatan Mandastana dalam Angka 2021,
2021.

[44] S. O. Idowu and W. Leal Filho, Global Practices of Corporate Social Responsibility. Berlin: Springer, 2009.

[45] J. J. Griffin and B. Vivari, United States of America: Internal commitments and external pressures, in Global Practices of Corporate Social Responsibility, Springer, 2009, pp. 235-250.

[46] M. S. Sarmila, R. Zaimah, N. Lyndon, M. Y. Hussain, and A. H. Awang, Local community economic wellbeing through CSR project, Mediterr. J. Soc. Sci., vol. 6, no. 4S3, pp. 79-87, 2015, doi: 10.5901/mjss.2015.v6n4s3p79.

[47] K. Magis, Community resilience: An indicator of social sustainability, Soc. Nat. Resour., vol. 23, no. 5, pp. 401-416, 2010.

[48] R. McCrea, A. Walton, and R. Leonard, Developing a model of community wellbeing and resilience in response to change, Soc. Indic. Res., vol. 129, no. 1, pp. 195-214, 2016.

[49] R. McCrea, A. Walton, and R. Leonard, A conceptual framework for investigating community wellbeing and resilience, Rural Soc., vol. 23, no. 3, pp. 270-282, 2014.

[50] E. Lawal, G. May, and B. Stahl, The significance of corporate social disclosure for high- tech manufacturing companies: Focus on employee and community aspects of sustainable development, Corp. Soc. Responsib. Environ. Manag., vol. 24, no. 4, pp. 295-311, 2017.

[51] L. Kong et al., CSR as a potential motivator to shape employees' view towards nature for a sustainable workplace environment, Sustain., vol. 13, no. 3, pp. 1-14, 2021, doi: 10.3390/su13031499.

[52] S. Brammer, A. Millington, and B. Rayton, The contribution of corporate social responsibility to organizational commitment, Int. J. Hum. Resour. Manag., vol. 18, no. 10, pp. 1701-1719, 2007.

[53] Y. Gao and A. S. Mattila, Improving consumer satisfaction in green hotels: The roles of perceived warmth, perceived competence, and CSR motive, Int. J. Hosp. Manag., vol. 42, pp. 20-31, 2014, doi: 10.1016/j.ijhm.2014.06.003.

[54] D. W. McMillan and D. M. Chavis, Sense of community: A definition and theory, $J$. Community Psychol., vol. 14, no. 1, pp. 623, 1986.

[55] S. B. Sarason, The psychological sense of 
community: Prospects for a community psychology. Jossey-Bass, 1974.

[56] T. R. Jimenez, A. Hoffman, and J. Grant, Theories, in Introduction to Community Psychology: Becoming an Agent of Change, L. Jason, O. Glantsman, J. O'Brien, and E. Al., Eds. 2019, pp. 83-96. [Online]. Available:

https://press.rebus.community/introductionto communitypsychology/

[57] E. F. Balcazar, C. B. Keys, and J. A. Vryhof, Empowerment, in Introduction to Community Psychology: Becoming an Agent of Change, L. A. Jason, O. Glantsman, J. F. O'Brien, and K. N. Ramian, Eds. 2019, pp. 183-200.

[58] A. M. McKune, Perceived Competence and Positive Well-being in Family Caregivers of Relatives with Alzheimer's Disease, Michigan State University, 1997.

[59] S. T. Baack, Analysis of Texas Nurses' Preparedness and Perceived Competence in Managing Disasters, University of Texas, 2011.

[60] J. F. Hair, W. C. Black, B. J. Babin, and R. E. Anderson, Multivariate Data Analysis, vol. 1, no. 2. Essex: Pearson Education Limited, 2014.

[61] G. Wilson, Community Resilience and Environmental Transitions. Routledge, 2012. doi: 10.4324/9780203144916.

[62] P. Devine-Wright, Place attachment and public acceptance of renewable energy: A tidal energy case study, J. Environ. Psychol., vol. 31 , no. 4 , pp. 336-343, Dec. 2011, doi: 10.1016/j.jenvp.2011.07.001.

[63] J. C. Anderson and D. W. Gerbing, Predicting the performance of measures in a confirmatory factor analysis with a pretest assessment of their substantive validities., $J$. Appl. Psychol., vol. 76, no. 5, p. 732, 1991.

[64] I. Ghozali, Structural Equation Modeling: Alternative Methods with Partial Least Square (PLS). Diponegoro Semarang Publishing Board, Semarang, 2014.

[65] J. C. Nunnally, Psychometric Theory. New York: McGraw-Hill book company, 1978.

[66] M. L. Barnett, I. Henriques, and B. W. Husted, Beyond good intentions: Designing CSR initiatives for greater social impact, $J$. Manage., vol. 46, no. 6, pp. 937-964, Jul. 2020, doi: $10.1177 / 0149206319900539$.

[67] S. Indarti and Y. Efni, Comparative study: The role of corporate social responsibility towards the development of entrepreneurial attitude and small medium-sized enterprises income, Pekanbaru, Indonesia, Int. J. Law Manag., 2018.

[68] L. A. Jason et al., Introduction to Community Psychology Becoming an Agent of Change, p. 409, 2019, [Online]. Available: https://press.rebus.community/introductionto communitypsychology/

[69] U. Idemudia and N. Osayande, Assessing the effect of corporate social responsibility on community development in the Niger Delta: A corporate perspective, Community Dev. J., 2018, [Online]. Available: https://academic.oup.com/cdj/articleabstract/53/1/155/2607769

\section{Acknowledgments:}

The authors wish to thank the managing editor, Ms. Maria Makrynaki, and the anonymous reviewers for their insightful advice throughout the review process.

\section{Contribution of individual authors to the creation of a scientific article (ghostwriting policy)}

Conceptualization, writing-original draft preparation, methodology, and resources by Laila Refiana Said. The investigation, data curation, and funding acquisition by Hastin Umi Anisah. Writing - review and editing by Laila Refiana Said and Hastin Umi Anisah. Validation and supervision by Muhammad Riza Firdaus. Formal analysis and project administration by Rusniati Rusniati.

Sofware and visualization by Muhammad Karunia Rachman. All authors have read and agreed to the published version of the manuscript.

\section{Sources of funding for research presented in a scientific article or scientific article itself}

Funding by Lambung Mangkurat University.

\section{Creative Commons Attribution \\ License 4.0 (Attribution 4.0 \\ International , CC BY 4.0)}

This article is published under the terms of the Creative Commons Attribution License 4.0 https://creativecommons.org/licenses/by/4.0/deed.en US 